\title{
Interactive comment on "Technical Note: PaleoDataView - A software toolbox for the collection, homogenization and visualization of marine proxy data" by Michael Langner and Stefan Mulitza
}

Michael Langner and Stefan Mulitza

smulitza@uni-bremen.de

Received and published: 1 October 2019

The comment was uploaded in the form of a supplement:

https://www.clim-past-discuss.net/cp-2019-59/cp-2019-59-AC2-supplement.pdf

Interactive comment on Clim. Past Discuss., https://doi.org/10.5194/cp-2019-59, 2019. 